\title{
BANK REFORM DEMANDS MONETARY REFORM
}

\author{
STEVE BAKER*
}

Fecha de recepción: 20 de mayo de 2013.

Fecha de aceptación: 25 de junio de 2013.

The complex and technical subject of bank reform has scarcely been more popular. Events in Cyprus have demonstrated banks are a way of investing money for a return, with all the risk that entails. Van and minibus entrepreneur Dave Fishwick has created a documentary - Bank of Dave - which shows banking can be a simple entrepreneurial function providing a safe return to savers at the entrepreneur's risk. It's award-winning and a soar-away popular success.

Of course, thanks to regulators, it's not actually a bank: it's a savings and loans firm. Whereas these route savings to borrowers, a bank creates credit. That is, banks lend money into existence. It is that distinction, together with other features of the financial system, which has led the world into crisis. It is both one of the least well-understood economic phenomena of our time and the most central to our present difficulties.

Yet, astonishingly, Dave Fishwick has struck on a model of banking close to a theoretical ideal: he carries his own commercial risks and, even if he could take deposits, he wouldn't provide credit in excess of savings.

It is towards this model the world should move.

* A version of this article was first published by the New Economics Foundation in Tolley, S. (ed.), Banking 2020: A Vision for the Future, London 2013. 


\section{I \\ THE FEATURES OF TODAY'S BANKING SYSTEM}

As Governor of the Bank of England Sir Mervyn King told us in 2010: «Of all the many ways of organising banking, the worst is the one we have today.»

Notes and coins are irredeemable: the promise to pay the bearer on demand cannot be fulfilled, except with another note or coin with the same face value. Notes and coins are tokens worth less than their face value and are issued lawfully and exclusively by the state. This is fiat money.

When this money is deposited at the bank it becomes the bank's property and a liability. The bank does not retain a full reserve on demand deposits. In the days of gold as money, fractional reserves on demand deposits explained how banks created credit. Today, credit expansion is not bounded by the redemption of notes, coins, and bank deposits in gold.

Because banks are funded by demand deposits but create credit on longer terms, they are risky investment vehicles subject to runs in a loss of confidence. States have come to provide taxpayerfunded deposit insurance. This subsidises commercial risk, producing more of it and creating moral hazard amongst depositors who need not concern themselves with the conduct of banks.

The state also provides a privileged lender of last resort: the central bank. It lends to illiquid but solvent banks getting them through moments of crisis. In a fiat money system, central banks have the power to create reserves and otherwise intervene openly in the money markets. Today this is most evident in the purchase of government bonds with new money, so-called quantitative easing.

The central banks also manipulate interest rates in the hope of maintaining a particular rate of price inflation through just the right rate of credit expansion to match economic growth. That otherwise free-market economists and commentators support such obvious economic central planning is one of the absurdities of contemporary life.

Compounding these flaws is the limited liability corporate form. Whereas limited liability was introduced to protect stockholders from rapacious directors, its consequence today is ensuring no one 
taking commercial risks within banks stands to share in the downside. This creates further moral hazard.

Regulatory decisions have been taken to encourage banks to make bad loans and dispose of them irresponsibly. Among these are the US Community Reinvestment Act and the present government's various initiatives to promote the housing market and further credit expansion.

Having insisted banks make bad loans, the regulatory state imposed the counterproductive International Financial Reporting Standards (IFRS) which can over-value assets and over-state the capital position of banks. This drives the creation of financial products and deals which appear profitable but which are actually loss-making. Since these notoriously involve vast quantities of instruments tied to default, the system is booby-trapped.

Amongst the many practical consequences of these policies was the tripling of the money supply (M4) in the UK from $£ 700$ billion in 1997 to $£ 2.2$ trillion in 2010. Credit expansion at this rate has had predictable and profound consequences including asset bubbles, sectoral and geographic imbalances, unjust wealth inequality, erosion of physical capital, excess consumption over saving, and the redirection of scarce resources into unsustainable uses. Moreover, credit cannot be expanded without limit. Eventually, the real world catches up with credit not backed by tangible assets: booms are followed by busts.

II

\section{OBJECTIVES FOR MONETARY REFORM}

This crisis first emerged in banking. We were then told it was a debt crisis. Shortly, it will be generally realised that most money is created as debt and therefore this is a monetary crisis. Bank reform will then properly become a matter of monetary reform. Any plan for bank reform must therefore also be a plan for monetary reconstruction.

The goals of reform must include:

- The privatisation of commercial risks which are now socialised. 
- The availability of bank accounts which provide safekeeping of money.

- Choice in currency.

- Prudent accounting rules.

- An end to systematic intervention in credit markets by central banks.

The following two proposals would deliver a free market in money and banking. Their authors differ passionately over the status of demand deposits but, in the end, they take two routes to systems whose differences are largely semantic. The merits of each proposal differ according to the circumstances and political realities in which reform becomes possible.

\section{Constitutional fiat money as a route to free banking}

Proposals for banking based on constitutional fiat money run in the tradition of Peel's 1844 Bank Charter Act and Irving Fisher's 100\% Money, published in 1935 and recently raised to prominence by the IMF. ${ }^{1}$ The essence of the proposal is to separate the monetary and credit functions of the banking system by requiring a $100 \%$ reserve for demand deposits. Under such a system, bank runs are impossible, banks cannot create money, and a major source of business cycles is reduced or eliminated. Current accounts effectively become vaults for safekeeping and banks provide credit by intermediating between savers and borrowers.

A robust, comprehensive, and consistent justification of fullreserve banking from legal and economic principles is provided in Jesús Huerta de Soto's treatise, Money, Bank Credit and Economic Cycles. Controversially, he argues that it is a fraud to hold less than a 100\% reserve against demand deposits of money, one with profoundly damaging consequences.

He identifies five stages in a process of reform, including central bank independence. The next and crucial steps for the UK may be summarised as follows:

1 «The Chicago Plan Revisited», Jaromir Benes and Michael Kumhof, IMF WP/ $12 / 202$. 
Reform is announced: bank depositors decide to what extent they wish to swap their deposits for shares in the investment funds to be created.

By legislative act, every bank deposit becomes the property of the depositor, redeemable in cash produced by the state.

Having removed the banks' liability to depositors, the equivalent assets are placed in investment funds. Shares are issued proportionately to relevant depositors. The remaining shares are exchanged for outstanding government debt and other state liabilities, converted into bonds.

At this point, banks are safe: bank credit must be backed by savings and demand deposits are fully reserved under clear contractual principles. Savings would not be under taxpayer guarantee but could be privately guaranteed for competitive advantage. Investment funds would provide for those seeking short-term returns. Money supply growth would be transparently in the hands of the central bank: currency debasement to fund public spending would be clearly understood as such.

Huerta de Soto's plan is not inflationary. Changing the status of demand deposits and pledging to redeem them in cash does not create new money. Expropriating those assets of the banks acquired through decades of state-sponsored credit expansion could clear the state's debts and provide for at least a substantial proportion of future liabilities to the public.

In the remaining stages of his proposal, Huerta de Soto sets out steps to abolish the central bank and to provide for commodity money and free choice in currency. Ultimately, he provides for complete freedom in money and banking subject to a $100 \%$ reserve on demand deposits.

Finally, after the reform, the monetary and fiscal environment would demand honest politics. Former Federal Reserve Chairman Alan Greenspan concisely explained why in his essay Gold and Economic Freedom. He wrote:

Under a gold standard, the amount of credit that an economy can support is determined by the economy's tangible assets, since every credit instrument is ultimately a claim on some tangible asset. But government bonds are not backed by tangible wealth, 
only by the government's promise to pay out of future tax revenues, and cannot easily be absorbed by the financial markets. A large volume of new government bonds can be sold to the public only at progressively higher interest rates. Thus, government deficit spending under a gold standard is severely limited. The abandonment of the gold standard made it possible for the welfare statists to use the banking system as a means to an unlimited expansion of credit.

That is why for 40 years our monetary arrangements have been not merely tolerated but encouraged: chronic credit expansion has facilitated the deficit spending necessary to support welfare states in excess of the tax base. This is the source of the debt crisis now engulfing mankind. A new, honest, and sustainable politics would be required by the new financial environment. This proposal provides that environment and a fiscal reset.

\section{Moving directly to free banking}

After the Huerta de Soto plan was published in 1998, credit expansion in the UK proceeded at an astounding pace, with the broad money supply more than tripling between 1997 and 2010. This produced various asset bubbles and other distortions in the structure of relative prices. The effect on banks has been worsened by imprudent IFRS accounting. It is therefore an open question whether bank assets are susceptible to Huerta de Soto's proposal.

An alternative route to deliver a free banking system without passing through constitutional fi at money has been brought forward, drawing on the work of Kevin Dowd and Richard Salsman, in an article for the Cobden Centre by Anthony J Evans. Under the title 2 days, 2 weeks, 2 months: A proposal for sound money, the plan proceeds as follows:

Over two days - ensure all operating banks are solvent:

- Deposit insurance is removed - banks will not be able to rely on government support to gain the public's confidence.

- The Bank of England closes its discount window, which currently helps banks insure against liquidity shocks. 
- Any company can freely enter the UK banking industry.

- Banks will be able to merge and consolidate as desired.

- Bankruptcy proceedings will be undertaken on all insolvent banks: suspend withdrawals to prevent a run; ensure deposits up to $£ 50,000$ are ring-fenced; write down bank's assets; perform a debt-for-equity swap on remaining deposits.

- Re-open with an exemption on capital gains tax to avoid unjust taxation on the new shares held by depositors.

Over two weeks - monitor the emergence of free banking:

- Permanently freeze the current monetary base.

- Allow private banks to issue their own notes.

- Mandate that banks allow depositors to opt in to $100 \%$ reserve accounts free of charge.

- Mandate that banks offering fractional-reserve accounts make public key information. These might include reserve rates, asset classes being used to back deposits, and compensation offered in the event of a suspension of payment but they could be decided by an appointed panel.

- Government sells all gold reserves and allows banks to issue notes backed by gold (or any other commodity).

- Government rescinds all taxes on the use of gold as a medium of exchange.

- Repeal legal tender laws so people can choose which currencies to accept as payment.

Over two months - the end of central banking:

- The Bank of England ceases its open-market operations and no longer finances government debt.

- The Bank of England is privatised (it may well remain as a central clearing house).

This reform swiftly establishes a free banking system and the monetary context for honest politics. Large-scale depositors will have been bailed in to banks as shareholders in what remain investment vehicles. Not stated in Evans's summary is Dowd's 
proposal to extend bank directors' liability which I brought forward in my Financial Institutions (Reform) Bill.

Unlike the Huerta de Soto plan, fractional-reserve demand deposits are permitted and there is therefore no provision to expropriate banks in such a manner as to offset public liabilities. In an environment without taxpayer-backed deposit insurance, however, it seems likely that $100 \%$ reserve accounts would be popular. It is not clear how they would be backed by cash: perhaps banks would obtain the necessary reserves by selling assets to government in exchange for new money with a similar affect on the public finances.

\section{III CONCLUSION}

We have lived through an era of monetary history unprecedented in the industrial age. Chronic credit expansion has significantly funded welfare states' deficit spending while eroding the stock of physical capital. We have come to a profound crisis of political economy: social democracy underpinned by easy money is ending.

That process of conclusion will be marked by a series of bubbles as desperate interventions are applied in an attempt to defibrillate stagnant economies. At some point, it will become apparent that these interventions are futile when some combination of widespread default and massive price inflation takes place. Rapid action will then be necessary to reinstate a basis for sustainable and just prosperity based on free-market capitalism without the systematic inervention in money and bank credit which is even now bringing us to calamity.

Finally, it is food for thought that Dave Fishwick, a van and minibus entrepreneur, has substantially invented an appropriate popular model without recourse to high theory or obedience to state regulation. 